\title{
26. PRELIMINARY REPORT ON THE OSTRACODES OF LEG 24
}

\author{
Richard H. Benson, Smithsonian Institution, Washington, D. C.
}

Nine samples were examined from each of two sites, 237 and 238, of DSDP Leg 24 from calcareous layers ranging in age from middle lower Eocene to Quaternary. Ostracodes were found in each sample (50 cc in size), with 153 specimens occurring in the oldest sample and often less than 10 in each of the younger samples. About 375 specimens in all were found.

The preservation of all specimens from Site 237 was good. Those specimens of the Oligocene from Site 238 were not well preserved, and their small size and the dominance of smooth taxa made identification difficult.

The study of ostracodes in the fossil record of the deep sea is in its beginning stages. Therefore, most of the taxa of this report are identified only to generic level, and some of these taxa are in themselves in an early state of understanding and description. A census of the assemblages follows:

\section{IDENTIFICATION OF OSTRACODE TAXA BY SITE AND SAMPLE}

Site $237\left(7^{\circ} 4.99^{\prime} \mathrm{S}, 58^{\circ} 7.48^{\prime} \mathrm{E} ; 1640 \mathrm{~m}\right)$

Sample 2-2, 50-56 cm; Quaternary:

$\begin{array}{lr}\text { Bairdia } & 1 \\ \text { Bradleya dictyon } & 3 \\ \text { Krithe } & 12 \\ \text { Macrocypris } & 1 \\ \text { Pontocypris } & 1 \\ \text { Wichmannella } & \frac{7}{25}\end{array}$

Sample 4-3, 50-56 cm; upper Pliocene: Agrenocythere radula

$$
\text { (Brady) } 1880
$$

Sample 6-4, 50-56 cm; lower Pliocene: Agrenocythere radula

(Brady) 1880

Krithe

\section{Krithe}

Wichmannella

25

Sample 8-2, 50-56 cm; lower Pliocene:

$\begin{array}{lr}\text { Abyssocythere } & 1 \\ \text { Bradleya dictyon } & 5 \\ \text { Cytherella } & 1 \\ \text { Krithe } & 7 \\ \text { Poseidonamicus } & 2 \\ \text { "Suhmicythere" } & 1 \\ \text { Wichmannella } & \underline{6}\end{array}$

Sample 11-4, 50-56 cm; late Miocene:

$\begin{array}{ll}\text { Agrenocythere } & 2 \\ \text { Bradleya } & 2 \\ \text { Krithe } & 2 \\ \text { Wichmannella } & \frac{1}{7}\end{array}$

Sample 16-4, 50-56 cm; middle Miocene: Agrenocythere

Bairdia

Bradleya

Cytherella

Krithe

Oxycythereis

Poseidonamicus

"Neoatlanticythere"

Wichmannella

$$
\begin{array}{r}
2 \\
5 \\
6 \\
2 \\
7 \\
1 \\
1 \\
5 \\
2 \\
\hline 31
\end{array}
$$

2

Sample 17-5, 50-56 cm; middle Miocene: "Paragrenocythere" 4

Bairdia 7

Cytherella 3

Eocytheropteron 2

Henryhowella 3

Krithe 11

"Neoatlanticythere" 5

Unidentified $\frac{2}{37}$

Sample 24-4, 50-56 cm; upper Eocene:

$\begin{array}{lr}\text { Abyssocythere } & 3 \\ \text { Agrenocythere } & 5 \\ \text { Argilloecia } & 14 \\ \text { Bairdia } & 25 \\ \text { Brachycythere? } & 1 \\ \text { Bythocythere } & 1 \\ \text { Cyprid? } & 14 \\ \text { Cythereis sp. } & 2 \\ \text { Cytherella } & 14 \\ \text { Cytherelloidea } & 3 \\ \text { Cytheropteron } & 4 \\ \text { Eocytheropteron } & 1 \\ \text { Krithe } & 31 \\ \text { Macrocypris } & 25 \\ \text { Oxycythereis } & 2 \\ \text { "Paragrenocythere" } & 12 \\ \text { Saipanetta } & 8 \\ & 153\end{array}$

Sample 30-4, 50-56 cm; middle-lower Eocene:

Argilloecia

Bairdia

Cytherella

Cytherelloidea

Glossicythereis 
$\begin{array}{lr}\text { Krithe } & 1 \\ \text { Macrocypris } & \frac{5}{16}\end{array}$

Site $238\left(11^{\circ} 09.21^{\prime} \mathrm{S}, 70^{\circ} 31.56^{\prime} \mathrm{E} ; 2844 \mathrm{~m}\right)$

Sample 2-5, 50-56 cm; upper Pliocene: Agrenocythere Krithe

\section{1}

$\frac{4}{5}$

Sample 6-3, 50-56 cm; upper Pliocene: Bairdia

Brachycythere mucronalatum

Krithe

Poseidonamicus

Wichmannella

Sample 10-4, 50-56 cm; upper Pliocene: Oxycythereis

Wichmannella

Unidentified

Sample 17-4, 50-56 cm; upper Miocene: Agrenocythere

Bairdia

Krithe

Sample 34-4, 50-56 cm; middle Miocene: Krithe Unidentified

Sample 38-4, 50-56 cm; middle Miocene: Cytherella

Sample 44-4, 50-56 cm; upper Oligocene:

Cytherella

"Suhmicythere"

Sample 51-4, 50-56 cm; middle Oligocene: Agrenocythere

Cyprids 1

Eocythereopteron

2

Krithe

Oxycythereis

"Submicythere"

\section{2}

1

6

1

$\frac{2}{12}$

\section{1 \\ 1 \\ $\frac{1}{3}$}

\section{1}

1

$\frac{1}{3}$

\section{1
$\frac{1}{2}$}

$\frac{2}{2}$

\section{$\frac{1}{2}$}

1

1

7

1

$\begin{array}{r}1 \\ 2 \\ \hline\end{array}$

Sample 53-5, 50-56 cm; middle Oligocene: Bairdia

Cyprids 1

\section{COMPARISON OF TAXA AND FAUNAL ASSEMBLAGES}

Few of the taxa found at Sites 237 and 238 have been described previously. Only three known species, Bradleya dictyon (Brady, 1880); Agrenocythere radula (Brady, 1880); and Poseidonamicus major (Benson, 1972b), late Neogene and Recent forms, were found. All of the rest are new, although their genera are either known or in the process of being described. Those generic names appearing here in quotes are manuscript names (nomen nuda) that soon will be formally described.
The most useful ostracodes are the highly ornate forms such as are shown in Plate 1. Subtle variations in the patterns of the carapace reticulum (the network of wall-like structures covering the surface) can be traced with identifiable pore structures and correlated with changes in size, strength, and shape of the carapace. The adaptive evolution of an ostracode phyletic lineage, therefore, can be followed by tracing minor changes in the reticulum.

In Recent ostracode faunas, the carapace valves tend to become larger and more delicate with increased depth, distance from shore (lower mechanical energy levels), and lower temperatures. Those living in the deep-sea (psychrospheric) are more ornate or have more highly developed and more delicate reticula than those in the warm, shallow coastal waters (thermospheric). All of the ostracodes found as fossils in the DSDP cores are benthic and without swimming larval stages. Therefore, the aspect of strength shown in the carapace structure is a good indicator of the temperature-mechanical energy levels present on the ocean floor at the time of deposition. Because the ostracodes are among the few benthic fossils found in the cores, proper notice of this fact should be made.

In particular, changes occurring within two ostracode lineages, (1) Agrenocythere and (2) "NeotlanticythereSuhmicythere" (Plate 1, Figures 3-5, 7, 8), are typical of those occurring in many ornate ostracodes in the evolution of the psychrospheric fauna from late Eocene to the present. It is immediately noticeable that the Paleogene forms are more massive than those of the Neogene, suggesting a progressive cooling of the waters, an increased viscosity of the water, and, therefore, a greater metabolic gradient for precipitation of the carbonate shells. This general trend can be recognized in DSDP cores taken in most parts of the world and is again reflected in the ostracode records of Sites 237 and 238.

As can be seen from an examination of the census of taxa from the two sites, the faunas do not change suddenly through time, although those of the Paleogene contain some names not readily identifiable with younger ones. These are generally ancestral genera whose lesser variation is geographic during these different time spans. This fact is not reflected in the morphologic differences between species of about the same age at Sites 237 and 238 . However, their abundances are quite different with the drop in numbers of individuals from the shallower (Site 237) to the deeper (Site 238) localities being very noticeable (Figures 1 and 2).

As is known from studies of the ostracodes of DSDP cores from most of the first 25 legs (Benson, in press), a great change in the ostracode faunas took place about 40 million years ago. Before this time, a warm, but deep, fauna can be found over several portions of the world from Campanian into the Eocene. Some change in this fauna takes place during this time interval, but it is gradual. Only minor elements of this fauna, which are common in the Atlantic (Leg 3), were found in the Indian Ocean in Leg 24.

The modern psychrospheric fauna, which is generally cosmopolitan throughout the world ocean floor, began gradually in late Paleogene and is well represented in the upper sections of the cores at Sites 237 and 238. There is no indication that these sites have ever been appreciably 


\section{U. Pliocene}
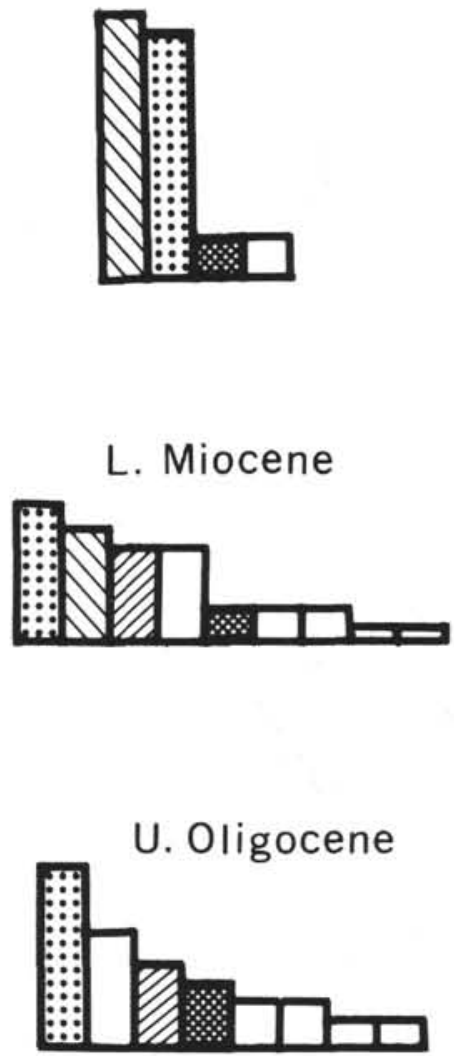

U. Eocene
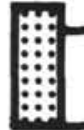

Figure 1. Changes in ostracode assemblage structure at four levels at Site 237 as shown in the relative abundance and rank of important species.

shallower than at the present time. A greater depth could have occurred, however. Unfortunately, we do not have sufficient control on the depth distribution of older taxa at present to amplify this possible change; we only notice the presence of Abyssocythere, which often has a greater depth range than the present sea floor now at Site 237.

A general change in diversity can be noted (Figure 2), especially in the record of Site 237, from the upper Eocene, when the diversity and abundance of ostracod taxa was high, to the Miocene and Pliocene where both the relative abundance and the diversity is much lower. Samples of equal size were taken, however, many other factors may complicate the significance of these changes to make a direct causal inference. It is noted that these same trends occur often in the deep-sea fossil ostracode record.
Site 237

Site 238
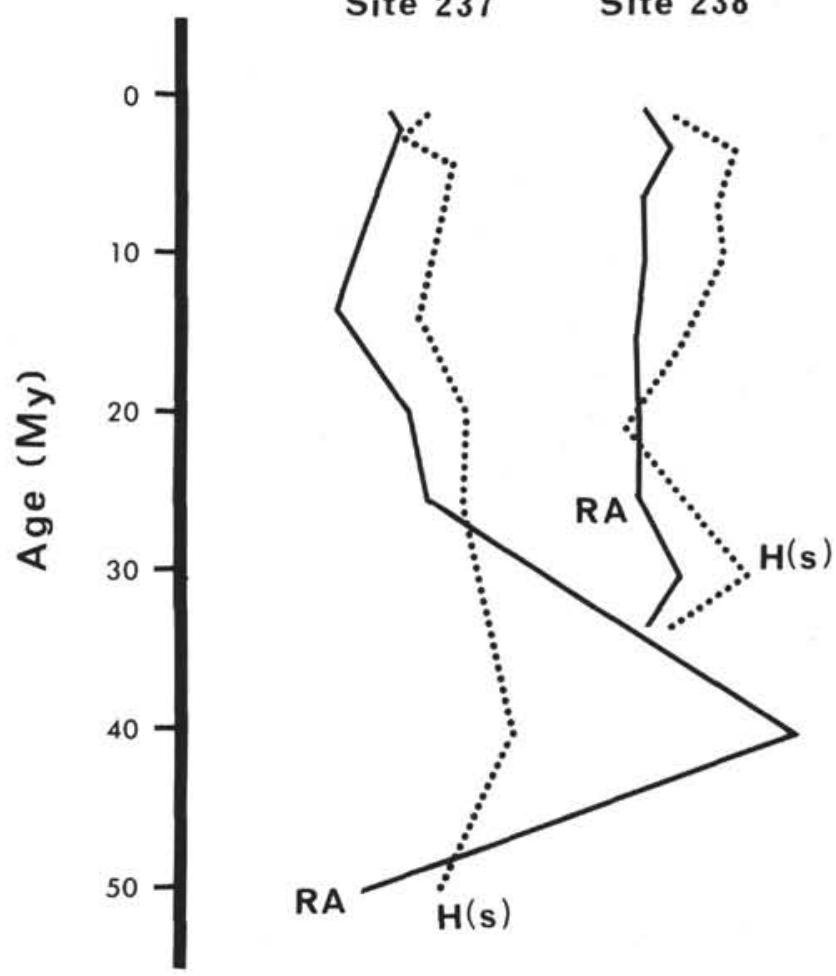

Figure 2. Changes in species diversity (Shannon-Weaver Function $\mathrm{H}_{(s)}$ ) and relative abundance (RA, number of specimens $150 \mathrm{cc}$ samples over $5-\mathrm{cm}$ core intervals) of ostracodes of Sites 237 and 238 (relationships among data drawn to the same scale).

\section{REFERENCES}

Benson, R. H., 1972b. The Bradleya problem, with descriptions of two new psychrospheric ostracode genera, Agrenocythere and Poseidonamicus (Ostracoda: Crustacea): Smithsonian Contrib. Paleobiol. v. 12, $138 \mathrm{p}$.

, in press. Morphologic stability in Ostracoda. In Proceedings of the Newark Symposium on Biology and Paleobiology of Ostracoda: Ithaca, New York (Bull. Am. Paleont.).

Brady, G. S., 1880. Report on the Ostracoda dredged by the H.M.S. Challenger during the years 1873-1876: Rept. Voyage Challenger, Zool. 1, 184 pp.

\section{ADDITIONAL BIBLIOGRAPHY}

Benson, R. H., 1969. Preliminary report on the study of abyssal ostracods. In Neale, J. W. (Ed.), the taxonomy, morphology and ecology of recent Ostracoda: Edinburgh, (Oliver \& Boyd), p. 475-480.

-1971. A new Cenozoic deep-sea genus, Abyssocythere (Crustacea, Ostracoda, Trachyleberidea) with descriptions of five new species: Smithsonian Contrib. Paleobiol., v. 7; 25 p.

, 1972a. Preliminary report on the ostracods of Holes 117 and $177 \mathrm{~A}$. In Laughton, A. S., Berggren, W. A., et al., Initial Reports of the Deep Sea Drilling Project, Volume XII: Washington (U.S. Government Printing Office), p. 427-432. 
1973a. Psychrospheric and continental Ostracoda from ancient sediments in the floor of the Mediterranean. In Ryan, W. B. F., Hsü, K J., et al., Initial Reports of the Deep Sea Drilling Project, Volume XIII: Washington (U.S. Government Printing Office), p. 1002-1008.

1973b. Ostracodes as indicators of threshold depth in the Mediterranean during the Pliocene. In Stanley, D. (ed.), Mediterranean Sea: (Dowden, Hutchinson \& Ross, Pa.) p. 47-57.

Benson, R. H. and Sylvester-Bradley, P. C., 1971. Deep-sea ostracodes and the transformation of ocean to sea in the Tethys. In Oertli, H. J. (Ed.) Proceedings Colloq. Paleoecol. Ostracoda. Pau, 1970, p. 63-92.
Swain, F. M., 1971a. Pleistocene Ostracoda from deep-sea sediments in the southeastern Pacific Ocean. In Funnell, B. M. and Riedel, W. R., (Eds.), The micropaleontology of oceans. Cambridge, England (Cambridge Univ. Press), p. $487-492$.

1971b. Pliocene ostracodes from deep-sea sediments in the southwest Pacific and Indian Ocean. In Funnell, B. M. and Riedel, W. R. (Eds.), The Micropaleontology of Oceans; Cambridge, England (Cambridge Univ. Press), p. 597-599.

1973. Upper Cretaceous Ostracoda from the northwestern Pacific Ocean: J. Paleontology, v. 47, p. 711-714. 


\section{PLATE 1}

Ostracodes from Sites 237 and 238.

Figure 1. "Paragrenocythere" sp.; left valve, adult male; SEM X 55, USNM 190977; Sample 237-17-5, 50-56 cm; upper Oligocene.

Figure 2 Bradleya aff. B. dictyon (Brady, 1880), left valve, adult female; SEM $\times$ 60, USNM 190974; Sample 237-2-2, 50-56 cm; Quaternary.

Figure 3,4 Agrenocythere radula (Brady, 1880), left and right valve, adult male, external and internal views; SEM $X$ 50, USNM 190975; Sample 238-10-4, 50-56 cm; mio-Pliocene transition.

Figure 5 Agrenocythere sp., left valve, adult female; SEM $\times$ 65, USNM 190979; Sample 238-51-4, 50-56 cm; middle Oligocene.

Figure 6 Poseidonamicus aff. P. major Benson, 1972b, left valve, adult female; SEM $\times$ 70, USNM 190976; Sample 237-8-2, 50-56 cm; upper Miocene.

Figure 7 "Neoatlanticythere" sp., left valve, adult male; SEM X 60, USNM 190978; Sample 237-17-5, 50-56 cm; upper Oligocene.

Figure 8 "Suhmicythere" sp., left valve, adult male?; SEM $X$ 60, USNM 190968; Sample 237-4-3, 50-56 cm; upper Pliocene. 
PLATE 1
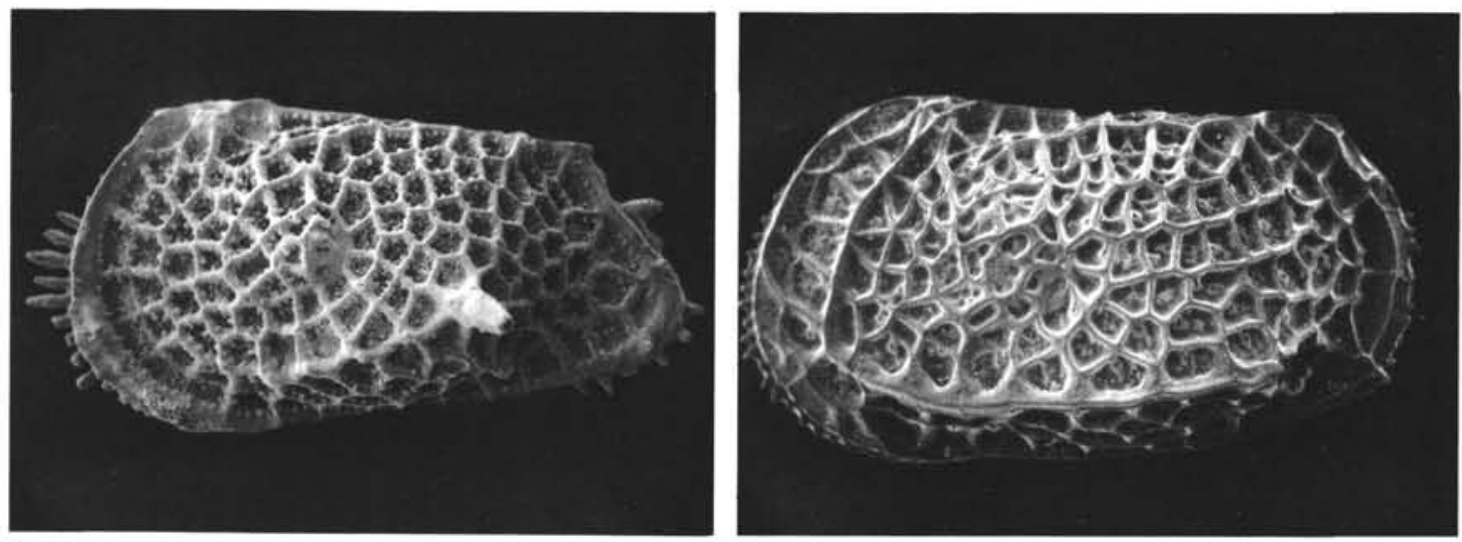

1

2
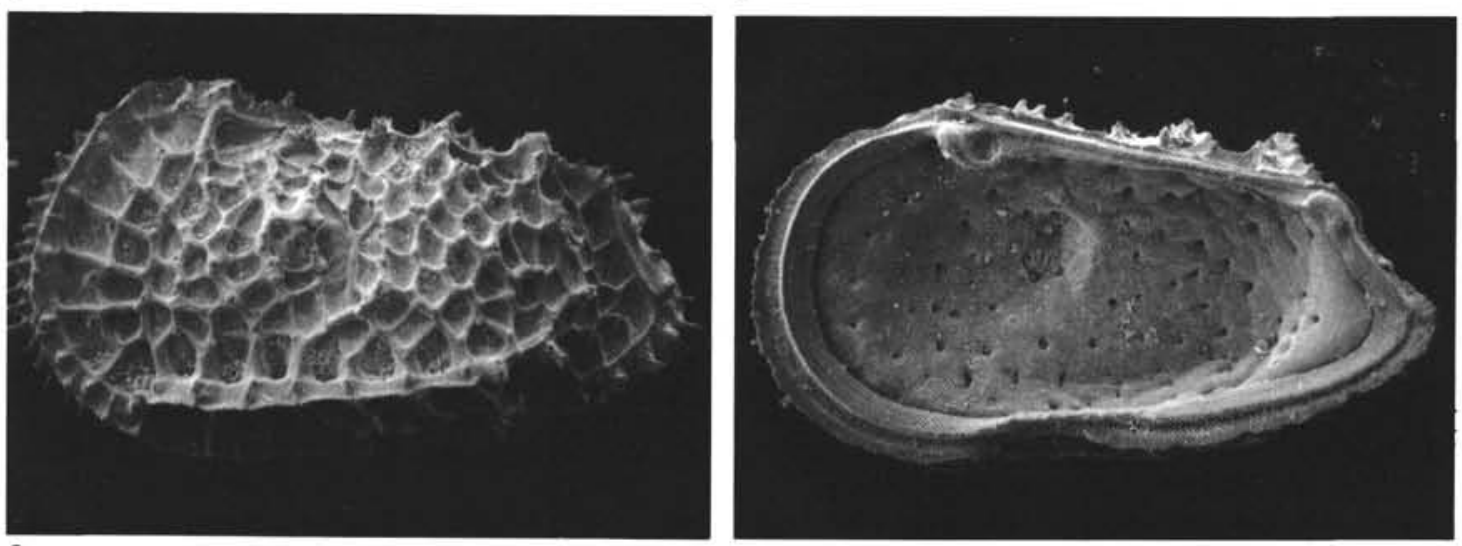

4
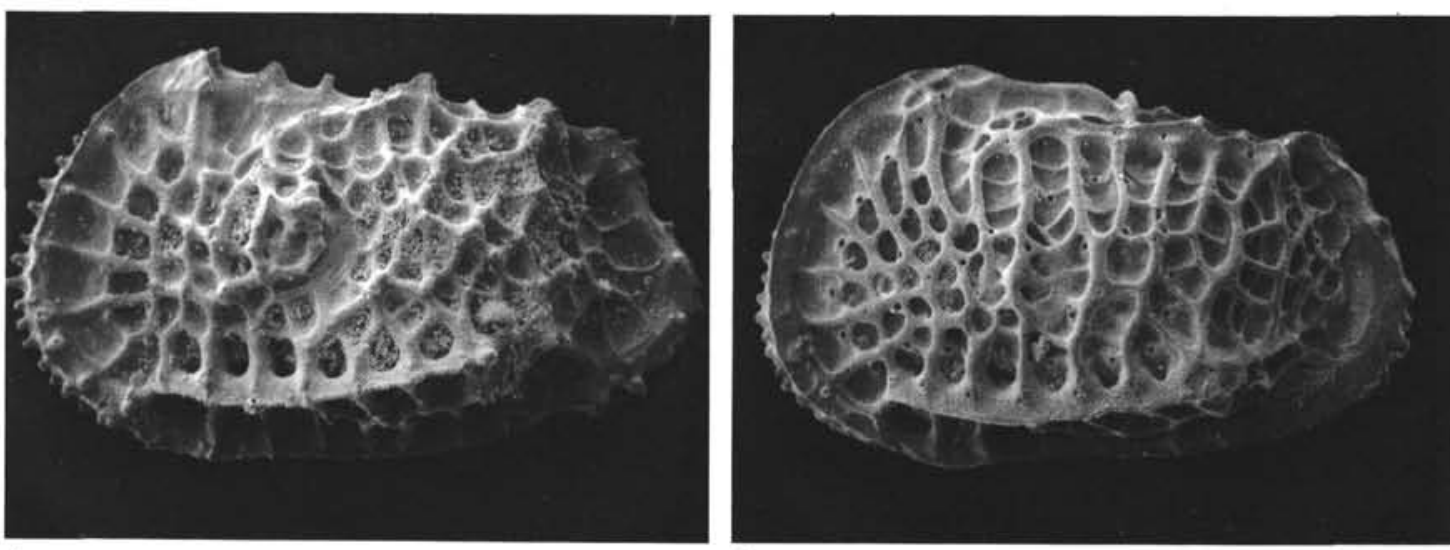

5

6
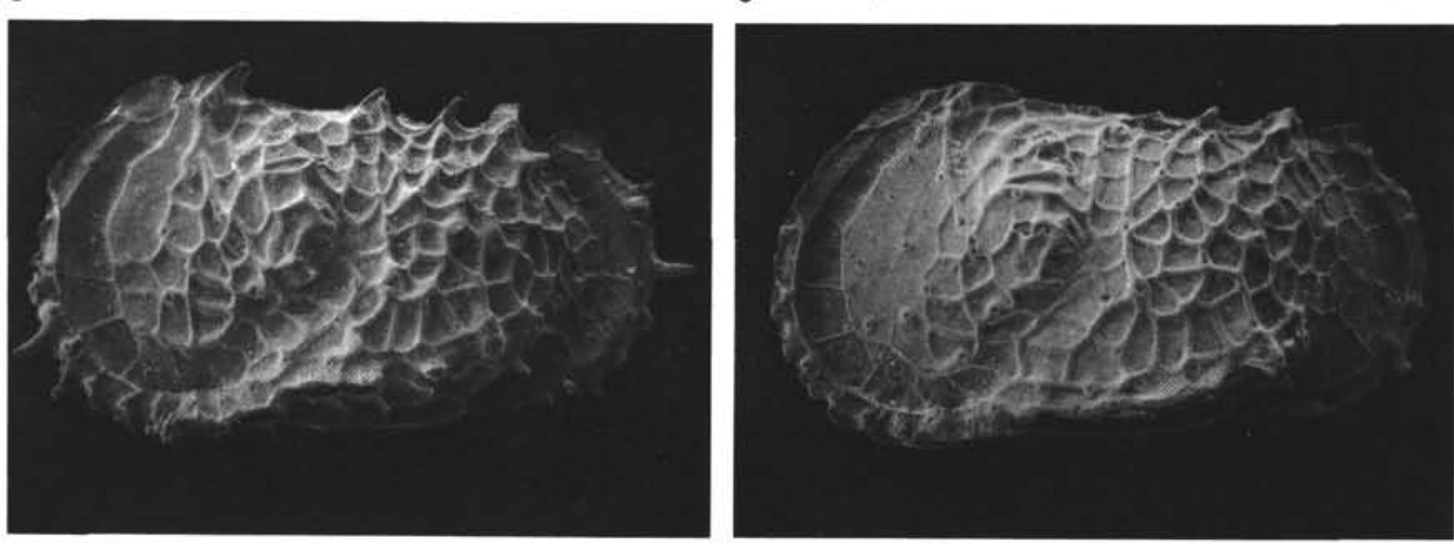